\title{
Pelestarian Kotagede Sebagai Pusat Pariwisata Heritage Kota Tua Di Yogyakarta
}

\author{
M. Fathurrahman Nurul Hakim \\ Akademi Pariwisata BSI Yogyakarta \\ E-mail: fathurrahman.mfh@bsi.ac.id
}

\begin{abstract}
Kotagede is a former Islamic Mataram kingdom where many historical and cultural heritage created in this area, both cultural heritage which is managed by the government or individuals, the Foundation kantil, foundations observer and preserver of cultural heritage in Kotagede, recorded prior to the May 2006 earthquake was recorded 151 residential houses shaped joglo cultural heritage preserved, but after the earthquake only 88 house of cultural heritage restoration works in the community after an earthquake is a lot of cultural heritage Conservationists popping thing that makes fit with the concept of community-based conservation, where the community is expected to contribute actif in the preservation and find yourself solutions to problems that occur. The role of government is expected to facilitate the training is held by the community in particular and society in the preservation Kotagede although this has been done by the department BP3 (Departement ancient heritage conservation) DIY but only on technical maintenance, but preparation of Tourism human resources in the sustained not seem real, it is still in need of a more mature preparation, especially in the regeneration of the preservation of cultural heritage and art that have Kotagede to sustainable tourism in order to meet people prospering Kotagede.
\end{abstract}

\section{Keyword: Conservation, Community, Tourism Sustainable}

Abstrak: Kotagede adalah bekas Kerajaan Mataram Islam di mana banyak sejarah dan Cagar Budaya tercipta di daerah ini, baik Cagar Budaya yang di kelola oleh pemerintah atau perorangan, Yayasan Kantil, adalah salah astu yayasan pemerhati dan pelestari Cagar Budaya di Kotagede, mencatat sebelum terjadinya gempa bumi Mei 2006 masih tercatat 151 rumah hunian Cagar Budaya yang berbentuk Joglo terpelihara, tetapi setelah gempa bumi hanya 88 Rumah Cagar Budaya yang berhasil di restorasi. Setelah gempa inilah banyak komunitas Pelestari Cagar Budaya bermunculan hal inilah yang membuat cocok dengan konsep pelestarian berbasis komunitas, di mana masyarakat di harapkan berperan actif dalam pelestarian ini dan menemukan sendiri solusi permasalahan yang terjadi. Peran Pemerintah di harapkan dalam memfasilitasi pelatihan yang di adakan oleh komunitas maupun masyarakat Kotagede khususnya dalam pelestarian walaupun hal ini telah di lakukan oleh dinas BP3 ( Balai pelestarian peninggalan purbakala ) DIY tetapi hanya sebatas pada tehnis pemeliharaannya saja, tetapi persiapan sumberdaya manusia dalam Kepariwisataan yang berkelanjutan belum tampak nyata, hal ini masih di perlukan persiapan yang lebih matang terutama dalam regenerasi pelestarian Cagar budaya dan seni yang di miliki Kotagede guna menyongsong Pariwisata yang berkelanjutan guna mencapai kemakmuran Pariwisata di Kotagede.

\section{Kata kunci: Pelestarian, Komunitas, Pariwisata berkelanjutan.}

\subsection{Latar Belakang}

Pembangunan yang berkelanjutan yang di laksanakan dewasa ini hakikatnya merupakan proses pembaharuan dan proses perubahan yang direncanakan sebelumnya. Sesuai dengan arah pembangunan nasional yang di tetapkan dalam Garis Besar Haluan Negara (GBHN), agar terwujud masyarakat yang adil dan makmur berdasarkan Pancasila dan Undang-undang Dasar 1945 didalam wadah Negara kesatuan Republik Indonesia (NKRI) yang merdeka berdaulat, bersatu, dan berkedaulatan rakyat dalam suasana kehidupan bangsa yang aman, tentram, tertib dan dinamis serta dalam lingkungan pergaulan dunia yang merdeka, bersahabat, tertib dan damai (Tap MPR RI No : II/MPR/1988, Bab II A).
Dengan berlakunya undang-undang Nomor 22 tahun 1999 tentang Pemerintah Daerah yang kemudian diatur lebih lanjut dengan peraturan Pemerintah Nomor 25 Tahun 2000 tentang perimbangan Keuangan Pusat dan Daerah, Pemberdayaan daerah semakin di tingkatkan. Semua daerah, baik Propinsi maupun Kabupaten berusaha untuk melakukan berbagai upaya meningkatkan pendapatan asli daerah guna membiayai Pembangunannya.

Pemberdayaan terhadap daerah merupakan peluang yang sangat besar bagi daerah untuk menggali dan mengembangkan potensi yang di miliki agar dapat dimanfaatkan secara optimal. Salah satu potensi yang di miliki tetapi memiliki tingkat pengembangan yang berbeda pada setiap daerah baik 
pengembangan subtansinya maupun manfaat ekonominya adalah produk pariwisata. Menurut James J. Spillane dalam ardhika (2007:59) dengan banyaknya wisatawan yang berkunjung pada suatu obyek wisata maka mengalirlah devisa Negara yang sangat segnifikan, harus di akui bahwa Indonesia pada saat ini masih jauh ketinggalan dalam menyerap arus wisatawan di bandingkan Negara di kawasan asia pasifik.

Dalam dunia pariwisata sebenarnya kita, tidak hanya akan menjaring wisatawan mancanegara saja tetapi juga wisatawan domestik. Dengan adanya kepariwisataan maka akan membuka sejumlah kegiatan sosial yang memungkinkan orang untuk berinteraksi, tukar menukar pengalaman, pemikiran dan pengetahuan, dengan demikian tidaklah dapat di hindari bahwa hal ini akan membawa kedalam perubahan. Berbagai Daya tarik wisata yang dapat di tawarkan terutama kepada wisatawan mancanegara, menurut Midleton dalam Yoeti (2010:27-31) antara lain adalah :

\section{Natural Atrraction}

Adalah daya tarik yang bersifat alamiah dan terdapat secara bebas dan dapat dilihat dan disaksikan setiap waktu. Seperti Pemandangan alam

2. Build Attraction

Yaitu bangunan-bangunan dengan arsitektur Kuno, jembatan, Rumah-rumah kunodan sebagainya.

3. Cultural Attraction

Peninggalan lama, petilasan, Candi dan musium.

4. Traditional Attraction

Tata cara hidup masyarakat tradisional adat istiadat dan kebiasaan separti pembakaran mayat (Ngaben) di Bali, upacara pemakaman mayat di tanah Toraja, upacara sekaten di Jogjakarata dan sebagainya.

Revitalisasi fisik dan budaya hingga saat ini terus di lakukan di Kotagede, sebagai cikal bakal berdirinya kerajaan Mataram Islam yang pertama.Kotagede di nilai mempunyai potensi menjadi World Heritage City.

Potensi bangunan cagar budaya Kotagede layak menjadi Word Heritage city, yang perlu secepatnya di bangun adalah "desain promosi dan kajian budaya secara lebih intens sehingga potret wajah Kotagede masa lalu bisa di gali lebih dalam", kata pengamat arsitektur sekaligus pemerhati Cagar Budaya dari Jepang Komihik Ono (TribunJogja.com :2012).

\subsection{Tinjauan Pustaka}

Pelestarian menurut kamus bahasa Indonesia berasal dari kata lestari yaitu penjagaan suatu bentuk barang atau perilaku agar tidak terjadi kepunahah sedangkan arti Pelestarian adalah usaha untuk menjaga suatu barang (benda) agar tidak terjadi kepunahan atau hilang.

Menurut UUD No. 9 Tahun 1990 Pariwisata adalah segala sesuatu yang berhubungan dengan wisata, termasuk pengusahaan objek dan daya tarik wisata serta usaha yang terkait di bidang tersebut. Jadi pariwisata dibutuhkan oleh orang-orang yang sedang melakukan perjalanan wisata dimana tempat tujuan mereka memiliki fasilitas layanan wisata yang dikelola oleh masyarakat, pengusaha dan pemerintah (Yulianto, 2017: 557). Pengertian Pariwisata Budaya adalah suatu Jenis kepariwisataan yang objeknya adalah kebudayaan. Ini dibedakan dari minatminat khusus lain seperti wisata alam dan wisata petualangan sedangkan objek wisata budaya berkisar pada beberapa hal seperti kesenian, tata busana upacara adat, boga dan lain-lain (Yoeti, 2012:26).

Kotagede atau KuthoGede mengandung pengertian Kota besar, di tinjau dari historisnya Kotagede sebagai pusat keprajan waktu kerajaan Mataram Islam I dan II yang kemudian keprabonnya di usung Sultan Agung kedaerah Pleret. Pariwisata berbasis Kemasyarakatan inilah yang sangat ingin ditonjolkan oleh pemerintah karena dalam pariwisata inilah semua element dan kemampuan masyarakat sangatlah dominan dalam menentukan kemajuan pariwisata berbasis kemasyarakatan, di dalam Pariwisata berbasis kemasyarakatan inilah masyarakat akan ikut dalam pelestarian kesenian dan budaya serta cagar budaya yang mereka miliki.

Garreth Shaw dan Allan M Williams dalam Ardika (2007: 64) menyatakan bahwa dalam kegiatan pariwisata terdapat sepuluh element budaya yang menjadi daya tarik wisatawan yakni: kerajinan, tradisi, sejarah dari suatu tempat/ daerah, arsitektur, makanan lokal/ tradisional, seni dan musik, cara hidup suatu masyarakat, agama, bahasa, dan pakian lokal/tradisional. Sedangkan Graburn dalam Ardika (2007:75) menyatakan bahwa dampak pariwisata terhadap budaya lokal dapat terjadi karena dilandasi oleh tiga hal yaitu :

1. Masyarakat ingin memberikan hasil karya seni ataupun kerajinan yang bermutu tinggi kepada wisatawan (pembeli)

2. Untuk menjaga citra dan menunjukan identitas budaya masyarakat lokal kepada masyarakat luar. 
3. Masyarakat ingin mendapatkan uang akibat meningkatanya komersialisasi.

Gee.C.Y. dan Fayos sola, Eduardo dalam Ardika (2007: 88) menyatakan bahwa generasi yang akan datang harus mendapatkan akses terhadap keragaman sumber daya alam dan budaya yang sama atau bahkan lebih dari yang ada saat ini. Oleh karena itu, pembanguanan Pariwisata di arahkan pada pengembangan pariwisata yang berkelanjutan. Prinsip-prinsip dalam pengembangan pariwisata yang berkelanjutan antara lain:

1. Wisatawan, perwakilan ataupun perusahaan yang bergerak di dalam bidang pariwisata harus menghormati kebudayaan, pandangan hidup dan perilaku masyarakat lokal.

2. Perencanaan pembangunan dan operational pariwisata haruslah bersifat lintas sektoral, terintegrasi, melibatkan pemerintah dan masyarakat lokal serta memberikan keuntungan bagi masyarakat secara luas.

3. Pariwisata harus dilaksanakan secara adil dan wajar didalam pendistribusian keuntungan dan biaya antara pelaku industri dan masyarakat lokal.

4. Pada seluruh tahapan pengembangan dan pelaksanaan pariwisata harus di lakukan penilian secara hati-hati, monitoring program, mediasipenyelesian sengketa dengan memberikan masyarakat lokal maupun pihak lain keuntungan dan kesempatan merespon perubahan.

\subsection{Metode Penelitian}

Pendekatan yang digunakan dalam penelitan ini bersifat deskriptif kualitatif. Analisis yang di peroleh berasal dari data-data kualitatif melalui proses pengamatan (observasi partisipasi), wawancara dan studi kepustakaan. Pengamatan dan wawancara yang mendalam dilakukan guna memperoleh pengertian dan gambaran nyata dari masyarakat yang di teliti, sedangkan studi kepustakaan dilakukan untuk mendapatkan pengertian mendasar dan kerangka teoritis penelitian untuk penulisan naskah selanjutnya.

\subsection{Hasil Penelitian Dan Pembahasan 4.1.1. Data Geografi Kotagede}

Luas keseluruhan wilayah kecamatan Kotagede adalah 3,07 $\mathrm{km}^{2}$. Dari area ini, 3,02 km2 berada pada ketinggian di bawah 100 $\mathrm{m} / \mathrm{dpa}$ dan $0,05 \mathrm{~km} 2$ berada pada ketinggian $100-99$ m/dpa. Wilayah kecamatan Kotagede adalah 9,45\% dari seluruh luas wilayah kota Yogyakarta yang mempunyai luas $32,5 \mathrm{~km}$.

Secara Administratif, berdasarkan SK Gubernur DIY Nomor: 48/KPTS/1985 tanggal
22 Pebruari 1985, wilayah kecamatan Kotagede dibagi menjadi 3 kelurahan, masing-masing adalah : Kelurahan Rejowinangun (luas 1,25 Km2), Kelurahan Prenggan $(0,99 \mathrm{~km} 2)$ dan Kelurahan Purbayan (0,83 km2). Masing-masing kelurahan terbagi dalam RT dan RW. Kelurahan Rejowinangun mempunyai $49 \mathrm{RT}$ dan $13 \mathrm{RW}$, Kelurahan Prenggan mempunyai $57 \mathrm{RT}, 13 \mathrm{RW}$ dan Kelurahan Purbayan mempunyai $58 \mathrm{RT}$ dan 14 RW.

\subsubsection{Peninggalan Heritage di kotagede}

\subsubsection{Pasar Kotagede}

Tata kota kerajaan Jawa biasanya menempatkan kraton, alun-alun dan pasar dalam poros selatan-utara. Kitab Nagarakertagama yang ditulis pada masa Kerajaan Majapahit (abad ke-14) menyebutkan bahwa pola ini sudah digunakan pada masa itu. "Pasar tradisional yang sudah ada sejak jaman Panembahan Senopati masih aktif hingga kini. Setiap pagi di hari Legi dalam kalender Jawa, penjual, pembeli, dan barang dagangan tumpah ruah di pasar ini. Sayangnya kualitas pasar tradisonal masih jauh dari standart kenyamanan, selama ini pasar masih belum di kelola dengan baik karena kurangnya kesadaran bahwa pasar memiliki potensi menjadi tempat wisata, kesadaran tentang kebersiham masih kurang bahkan ruang untuk jalan dan bahu jalan di gunakan untuk tempat parkir sehingga menambah kemacetan dan ketidak nyamannya suasana pasar Bangunannya memang sudah direhabilitasi, namun posisinya tidak berubah.

\subsubsection{Masjid Mataram}

Masjid Mataram Merupakan Masjid utama kerajaan, dimana segala kehidupan keagamaan Islam negara diselenggarakan. Mesjid Mataram memiliki sejumlah nama lain yang terkait dengan peran dan fungsinya, yakni Masjid Agung, Masjid Gedhe, Masjid Jami'. Masjid Mataram terletak di selatan Pasar Kotagede, barat Kampung Alunalun.Masjid berdiri dalam satu kompleks dengan Pasareyan Agung Kotagede, dikelilingi oleh tembok pasangan bata setinggi sekitar 2,5 meter. Masjid memiliki dua gerbang, yakni gerbang utama untuk jamaah di sisi timur dan gerbang pelayanan untuk kaum kudus di sisi utara.

Denah bangunan utama berbentuk bujur sangkar, ditutup dengan dinding tembok bahan batu putih. Atap utama adalah tajug tumpang tiga, didukung oleh empat tiang utama saka guru dari kayu. Di dalam ruang utama terdapat sebuah mimbar yang konon berasal dari Palembang. Kelengkapan ruangan mesjid antara lain adalah pawestren yaitu serambi 
khusus untuk kaum wanita yang berada di sebelah sisi selatan. Selain itu juga terapat serambi depan yang dikelilingi oleh parit.

Dalam struktur keruangan pusat kerajaan Islam di Jawa, Masjid Mataram merupakan salah satu elemen pokok catur gatra Kotagede sebagai kuthanegara kerajaan Mataram, terletak di sisi barat Alun-alun. Masjid ini adalah pusat sakral kerajaan. Di balik Masjid dimakamkan orang-orang yang mempunyai kaitan erat dengan keberadaan kerajaan Mataram.Dengan demikian area ini memiliki nilai religius sekaligus spiritual yang sangat tinggi bagi Keraton Mataram. Masjid ini adalah juga sebuah simbol dan tengaran masuknya Islam ke dalam masyarakat tradisional di pedalaman Jawa yang pada saat itu masih didominasi oleh kepercayaan asli dan Hindu. Kepercayaan asli muncul dalam penataannya yang menyatu dengan makam para tokoh, sedang karakter Hindu terlihat pada langgam rancangan pagar keliling dan gapura.

Bangunan masjid merupakan salah satu bangunan tertua noncandi di wilayah Yogyakarta, meski sudah mengalami beberapa kali renovasi, dan telah dimasukkan dalam bangunan yang harus dilestarikan. Bahwa ini adalah masjid kerajaan ditandai di antaranya dengan mustaka yang berciri khas mesjid keprabon. Arsitektur masjid pada ruang sholat utama menggunakan tipe bangunan tajug. Bangunan serambi Mesjid ditutup dengan atap limasan, emperan menggunakan konstruksi kuda-kuda sederhana (trusses), sedang kuncung-nya berupa pelana atau kampung.

Dalam sejarahnya, pada masa Pemanahan awalnya masjid masih berupa langgar (Surau kecil). Oleh Senapati, bangunan langgar ini kemudian dipindahkan atau digeser menjadi cungkup makam, sedangkan di tempat tersebut didirikan bangunan mesjid induk. Hal itu terjadi tahun 1587, sebagaimana tertera pada kelir gapura mesjid. Tahun itu adalah saat keruntuhan Pajang, dan pendirian kerajaan Mataram. Dengan demikian Mesjid Mataram menandai saat penobatan Senapati menjadi raja di Keraton Mataram.

4.1.2.3. Kompleks Makam Pendiri Kerajaandan Sendang seliran

Disebelah barat dari Masjid Mataram terdapat makam para pendiri kerajaan Mataram Islam yang dikelilingi tembok yang tinggi dan kokoh. Gapura ke kompleks makam ini memiliki ciri arsitektur Hindu.Setiap gapura memiliki pintu kayu yang tebal dan dihiasi ukiran yang indah. Beberapa abdi dalem berbusana adat Jawa menjaga kompleks ini 24 jam sehari.
Untuk memasuki kawasan ini terdapat 3 gapura, sebelum sampai ke gapura terakhir yang menuju bangunan makam. Untuk masuk ke dalam makam, kita harus mengenakan busana adat Jawa (bisa disewa di sana). Pengunjung hanya diperbolehkan masuk ke dalam makam pada Hari Minggu, Senin, Kamis, dan Jumat pukul 08.00 - 16.00.Untuk menjaga kehormatan para pendiri Kerajaan Mataram yang dimakamkan di sini, pengunjung dilarang memotret/membawa kamera dan mengenakan perhiasan emas di dalam bangunan makam.

Tokoh-tokoh penting yang dimakamkan di sini meliputi: Sultan Hadiwiijaya, Ki Gede Pemanahan, Panembahan Senopati, dan keluarganya. Tempat ini dikelola oleh dua kerajaan, bangsal pertama dari arah masjid di miliki oleh kerajaan Yogyakarta yang sekarang menjadi tempat untuk penjualan souvenir dan bansal kedua setelah memasuki gerbang kedua di kelola oleh kerajaan solo (Kasunanan), Kearah selatan dengan agak sedikit turunan yang terjal dengan undak berundak kita akan menjumpai sendang seliran, sendang ini terbagi menjadi dua yang sebelah utara di sebut dengan sendang kangkung dan sebelah selatan sendang putri konon sendang ini di gunakan untuk para keluarga kerathon, dan sekarang tempat ini digunakan oleh penduduk dan para peziarah untuk mandi serta di ambil airnya untuk ritual.

\subsubsection{Rumah Tradisional}

Persis di seberang jalan dari depan kompleks makam, bias terlihat sebuah rumah tradisional Jawa. Namun bila mau berjalan 50 meter ke arah selatan, akanterlihat sebuah gapura tembok dengan rongga yang rendah dan plakat yang yang bertuliskan "cagar budaya". Masuklah ke dalam, di sana akan terlihat rumah-rumah tradisional Kotagede yang masih terawat baik dan benar-benar berfungsi sebagai rumah tinggal.Yayasan kantil yang bergerak di bidang pelestarian Cagar Budaya Kotagede mencatat hingga tahun 2005 masih ada sekitar 151 bangunan joglo, dan setelah terjadinya gempa bumi pada bulan mei 2006 hanya 107 yang tersisa itupun banyak yang rusak parah dan 88 rumah joglo harus di restorasi, Perumahan tradisional di kotagede adalah asset utama yang di miliki Kotagede, karena keunikkannya, terlihat dari jalan rukunan yang terbentuk dari deretan rumah-rumah tradisional, Jalan rukunan merupakan tempat berinteraksi para warga yang bertempat tinggal disana dan dapat diakses oleh Masyarakat sekitar, Hal yang membuat menarik adalah jalan rukunan bukanlah milik umum, melainkan areal tersebut masih dalam kesatuan lahan rumah 
masyarakat yang secara sengaja terhubung antara rumah satu dengan lainya yang membentuk jalan.

\subsubsection{Kedhaton}

Arah keselatan dari rumah Joglo Terdapat Pabrik Coklat Monggo yang berada dalam komplek Kerajaan atau yang disebut dengan kampung Dhalem, tepat di bawah 3 Pohon Beringin yang berada di tengah jalan. Di tengahnya ada bangunan kecil yang menyimpan "watu gilang", sebuah batu hitam berbentuk bujur sangkar di sinilah Raja Mataram I dan II, Bertahta yang permukaannya terdapat tulisan yang disusun membentuk lingkaran: Ita Moventur Mundu S Ainsi Va Le Monde - Z00 Gaat De Wereld Cosi Van II Mondo. Di Luar Lingkaran Itu Terdapat Tulisan Ad Atern Am Memoriam Infelics - In Fortuna Consoertes Digni Valete Quidstperis Insani Videte Ignari Et Ridete, Contemnite Vos Constemtu - IGM (In Glorium Maximam).

Dalam bangunan itu juga terdapat "watu cantheng", tiga bola yang terbuat dari batu berwarna kekuning-kuningan. Masyarakat setempat menduga bahwa "bola" batu itu adalah mainan putra Panembahan Senapatiyang bernama Raden Ronggo untuk bermain gatheng. Namun tidak tertutup kemungkinan bahwa benda itu sebenarnya merupakan peluru meriam kuno ujarnya.

\subsubsection{Reruntuhan Benteng}

Panembahan Senopati membangun benteng dalam (cepuri) lengkap dengan parit pertahanan di sekeliling kraton, luasnya kirakira 400 × 400 meter. Reruntuhan benteng yang asli masih bisa dilihat di pojok barat daya dan tenggara. Temboknya setebal 4 kaki terbuat dari balok batu berukuran besar. Sedangkan sisa parit pertahanan bisa dilihat di sisi timur, selatan, dan barat.

\subsubsection{Seni dan Budaya yang di miliki Kotagede}

\subsubsection{Purba Budhaya, Srandhul}

Kesenian tradisional Srandul ini bentuk maupun busana yang digunakan mirip seperti kethoprak ongklek (ketho-prak barangan). Alat-alat instrumen gamelan yang digunakan, antara lain: saron peking, kendhang, kethuk kempul, gong, dan lain-lain. Ciri khas Srandhul Kotagede, yakni mereka tidak menggunakan ongklek sebagai tempat menggantung gamelan ketika dipikul ngamen.Gamelan tetap diletakkan di tempat. Sebagai titik perhatian, di tengah arena ditempatkan oncor (obor) dengan lima batang sumbu. Di bawah oncor, ada tiang penyangga yang dihiasi dengan berbagai macam daun dantanaman, Purba Budhaya terletak di Kampung Bumen Kotagede. Kelompok yang beranggotakan kurang lebih 35 orang, di bawah pimpinan Basis Hargito, setiap pentas tidak pernah lupa melengkapi dengan ubarampe sesaji seperti tukon pasar (jajan pasar), kembang setaman, dan menyan/dupa. Beberapa lakon yang pernah dipentaskan, dari beberapa babad yaitu: Babad Arab, cerita yang dikisahkan tentang Sayidina Ali dalam lakon Pedang Kangkam Pamor Kencana Musna; Babad Jenggala, lakon Kethek Ogleng; Babad Demak, dengan lakon Perawan Sunthi, dan; Dongeng Rakyat, dengan cerita Andhe-Andhe Lumut, Jaka Bodho, Jaka Wasis, dan sebagainya.

\subsubsection{Wayang Thingklung}

Merupakan salah satu jenis ke-senian wayang kulit yang secara khas masih bertahan di Kotagede. Ciri spesifik wayang thingklung adalah dhalang selain berperan menguasai jalan cerita dan memainkan wayang, juga melantunkan sendiri instrumen pengiring dengan suaranya. Sehingga dalam wayang thingklung tidak ada pengiring apapun, baik waranggana/sindhen maupun instrumen gamelan. Dhalang dituntut untuk mampu menirukan suara gamelan pengiring dan menyelaraskannya dengan dialog-dialog di setiap lakon yang muncul. Pada awalnya wayang ini menggunakan bahan kardus/karton namun kemudian di-ganti dengan bahan kulit. Salah satu dhalang wayang thingklung yang ada di Kotagede bernama Mujiran alias Ki Tjermo Mudjihartono dari Dusun Karangduren. Pada beberapa kesempatan pentas, sering dikenal dengan nama Tjermo SM. Singkatan dari Tjermo Sumedi dan Marijan. Seperangkat wayang kulit yang dimilikinya merupakan koleksi pribadi. Lakon-lakon yang sering dibawakannya adalah Babad Alas Martani, dan Antasena Takon Bapa. Keberadaan wayang thingklung ini pada awalnya menjadi salah satu seni pertunjukan yang khas bagi kesenian wayang yang berkembang di Kotagede. Beberapa dhalang yang lain, ada-lah Ki Wajiman yang beralamat di Purbayan, dan Ki Parjudi yang beralamat di Gedhongan.

\subsubsection{Timpasko, Keroncong}

Kelompok peduli seni musik keroncong yang berkedudukan di sebelah timur Pasar Kotagede. Visi dan misi kelompok ini, ingin melestarikan seni musik sebagai hiburan rakyat. Kelompok sejenis perkembangannya cukup pesat, bahkan ada beberapa kelompok yang lain, antara lain: Angkasa, Bhagaskara, Cahaya Muda, Candrakirana, Citra Nada, Dasa Irama, Gema Irama, Gema Sangkakala, Irama Asih, Irama Asti, Kharisma, Nada Kencana, Ngesti Irama, Purnama Nada, Rias Purnama, Sapta Irama, Sederhana, Sehati, 
Setia Nada dan Sinar Baru. Di Kotagede, kelompok dan perkumpulan keroncong berkembang dengan pesatnya. Ada beberapa aliran keroncong seperti, Keroncong Dhangdhut, Keroncong Campursari dan Keroncong Rock. Keroncong adalah musik yang sudah lama berkembang di Indonesia dengan irama khas. Pada awalnya untuk memainkan keroncong terdiri dari alat-alat akustik, seperti: bas benthot, celo pethik, melodi gitar, ukulele dan chack. Alat-alat tersebut masih ditambah dengan perlengkapan lain seperti biola, dan flute. Biasanya keroncong dimainkan oleh tujuh orang. Tetapi semakin banyak semakin baik. Keroncong dapat dibagi sekurangnya dalam empat jenis:

1. Keroncong asli dengan lagu-lagu, Dewi Murni, Telomoyo, dan Keroncong Suci.

2. Langgam Keroncong, dengan lagu-lagu, Kota Solo, Rangkaian Melati dan Sungai Serayu.

3. Stambul I, dengan lagu-lagunya, Baju Biru, Stambul Kecewa dan Terkenang.

4. Stambul II, dengan lagu-lagunya, Yen ing Tawang Ana Lintang, Lara Branta dan Wuyung.

\subsection{Model Pelestarian Heritage di Kotagede.}

Dunia Pariwisata di Kotagede memiliki Karakteristik Khusus, situs sejarahnya menyatu dengan kehidupan Masyarakatnya, kerajianan industri perak menjadi keseharian serta kesenian Tradisional tumbuh dari ritual warganya.

Menurut Muhammad Nassir ketua Yayasan Kantil "Kotagede amat sesuai dengan Konsep Community Based Tourism (CBT), dari konsep tersebut kita bisa melihat bahwa kesadaran akan pentingnya pengembangan Pariwisata yang nyaman di Kotagede Bukan berarti tidak tumbuh sama sekali, Geliat warga untuk terus berjuang membangun, melakukan promosi dan perbaikan secara terus menerus dan berkelanjutan, Banyak Organisasi yang berbasis komunitas seperti Yayasan Kanthil, Yayasan Pusat Dokementasi Kotagede, Forum Joglo, Organisasi Pelestari Kawasan Pusaka (OPKP), serta keterlibatan warga dalam berbagai program pengembangan kawasan seperti aksi pemetaan potensi oleh komunitas Grrenmap dan Java Recontruction Fund (JRF) serta pelatihan"

Sedangkan menurut Bp Achmad Charis Zubair (Tokoh Masyarakat ). Pada dasarnya pelatihan berbasis masyarakat merupakan suatu gerakan untuk memberikan kepercayaan kepada masyarakat untuk berperan aktif membangun sikap mau melakukan sesuatu dari dalam diri mereka. Hal ituberlandaskan pada pandangan bahwa dari lingkungan masyarakat itu sendiri memiliki potensi besar untuk memperbaiki kehidupan dengan berbagai kiat yang yang di miliki, sedangkan proses pendampingan pada dasarnya merupakan bagian bagian dari penguatan kapasitas dan stimulus yang didasarkan pada kebutuhan masyrakat menuju pelestarian kawasan pusaka kotagede yang berkelanjutan. Pada perkembangnya pendampingan ini akan memunculkan sikap, pemahaman, peran, serta dan ketrampilan masyarakat untuk mengelola persoalan secara mandiri, melalui model pendekatan pendampingan situasional yaitu dengan melihat dan memahami tingkatan perkembangan masyarakat Kotagede.

Organisasi-organisasi ataupun lembagalembaga baik pemerintah maupun non pemerintah (Swasta dan Masyarakat) bisa melakukan pemberdayaan melalui program pendampingan yang sesuai dengan kemampuan dan kemauan masyarakat, maka proses pendampingan akan berjalan secara optimal, komprehensif dengan hasil yang lebih efektif, Model pendampingan berbasis masyarakatini diterapkan untuk membangun pembelajaran dan peningkatankemampuan masyarakat Kotagede secara langsung dan intergratif. Hasil yang diharapkan lebih lanjut adalah pengembangan kretivitas yang berorientasi praktek serta peningkatan pengetahuan organisasi pengelolaan kawasan Pusaka yang mandiri berbasis masyarakat.

\subsection{Peran Masyarakat dan Stakeholder dalam Pelestarian Heritage Kota Tua Islam di Yogyakarta}

Setelah terjadi gempa pada tahun 2006 yang dulunya cagar budaya di kotagede kurang lebih ada 151 Rumah joglo sekarang hanya tinggal 88 yang berhasil di selamatkan hal ini tak luput dari peran Masyarakat serta pihak swasta dan pemerintah. Sejumlah organisasi di Kotagede di bentuk, berawal dari kegiatan Java Recontruction Fund Rehabilitasi dan Rekontruksi Masyarakat dan pemukiman berbasis Komunitas (JRF - Rekompak) Untuk melestarikan Heritage di Kotagede maka terbentuklah Organisasi Pelestari Kawasan Pusaka Kotagede Di masing-masing Kelurahan di kotagede terwadahai dalam Satu Wadah Yaitu Forum Joglo Ketua Forum Joglo Organisasi Ini bertujuan untuk melestarikan warisan Budaya di Kotagede Baik tampak (tangible) maupun yang tidak tampak (Intangible) agar bisa dimanfaatkan untuk mencukupi perekonomian dan kesejahtreaan masyarakat sendiri. 
Setelah gempa terjadi bantuan mengalir dari dalam dan luar negeri maupun penjuru dunia untuk membangun kembali artefak (Rekontruksi) dan memulihkan kembali (Rehabilitasi) kehidupan masyarakat yang terkena gempa. Program bantuan yang berupa dana dan pendampingan dari Program REKOMPAK-JRF (Java Reconstruksion Fund) misalnya di salurkan ke komunitas- komunitas lokal melalui BKM (Badan kesejahteraan Rakyat) dan dalam pelaksanaannya di lakukan oleh Departemant Pekerjaan Umum bekerjasama dengan Masyarakat Lokal.

Pelestarian dan pengelolaan kawasan kotagede sebagai cagar budaya telah di kukuhkan dengan penandatangan nota kesepahaman (MoU) oleh Gubernur DIY Sri Sultan Hamengku Buwono $X$, Walikota Yogyakarta Herry Zudianto, dan Bupati Bantul Sri Suryawidati di Omah UGM Desa Jagalan, Banguntapan Bantul. Pada tanggal 11 April 2011, MoU ini di harapkan sebagai landasan yang kuat bagi semua pihak yang terlibat dalam pengelolaan kawasan pusaka Kotagede yang berkelanjutan. adalah :

Di antara program yang telah dilakukan

1. Program Jogjakarta Heritage Society (JHS) bekerjasama dengan UNESCO

Kegiatan ini adalah penyusunan pedoman tentang bangunan tradisional di kawasan Kotagede yang di laksanakan oleh Jogjakarta Heritage Society (JHS) bekerjasama dengan UNESCO. Dalam kegiatan tersebut masyarakat bersama pihak terkait sebagai narasumber, peserta kegiatan dan kelompok swadaya memberikan masukan serta terlibat dalam membuat format pedoman pelestarian bangunan tradisional mereka sendiri. Keluaran program tersebut adalah buku pedoman tentang konservasi bangunan Tradisional.

2. Program JHS bekerjasama dengan Perguruan Tinggi (UGM)

Ini adalah program rekontruksi dan rehabilitasi bangunan Pusaka Budaya di Kotagede yang melibatkan komunitas lokal, JHS dan perguruan tinggi (UGM). Keluaran program ini adalah rekontruksi bangunan yang runtuh akibat gempa bumi mei 2006 yaitu dengan melakukan rehabilitasi bangunan joglo yang di fungsikan sebagai fasilitas public yang di sebut dengan "Omah UGM" yang sekarang di manfaatkan sebagai basecam dan pusat dokumentasi pelestarian Kawasan Pusaka Kotagede.

3. Program Balai Pelestarian Peninggalan Purbakala (BP3) DIY
Merupakan Program pemeliharaan bangunan pusaka budaya di kawasan Kotagede yang di laksanakan oleh BP3 DIY. Di dalam kegiatan ini dilakukan kegiatan pembinaan tehnis atau pelatihan tenntang pemeliharaan bangunan tradisional kepada Masyarakat dan tehnisi pelaksana, Sebagai lembaga pemerintah BP3 menerapkan pendampingan secara birokratis dari tingkat yang mendasar.

4. Program REKOMPAK - JRF

Program Rekontruksi lingkungan dan perumahan Kawasan Kotagede yang di danai olehWord bankJRF yang bekerjasama dengan organisasi pendamping REKOMPAK, pemerintah desa dan intasi pemerintah (PU/Kimpraswil). Pelaksanaan tersebut melakukan bimbingan identifikasi lingkungan perumusan permasalahan dan perencanaan untuk implementasi program.Dimana salah satu komponen program REKOMPAK untuk masyarakat desa adalah bantuan tehnik dan pendampingan.

\subsection{Kesimpulan}

Dari uraian bahasan dan analisa data sebelumnya, maka penulis dapat menarik kesimpulkan bahwa :

1. Pelestarian berbasis komunitas sangatlah cocok di terapkan di Kotagede guna Pelestarian Cagar Budaya yang di milikinya, Pelestarian berbasis Komunitas yaitu Pelestarian yang terorganisir yang di bentuk oleh Masyarakat Kotagede yang mengupayakan Pelestarian yang terarah dan berkesinambungan Guna pemanfaat Potensi yang ada, sekaligus menumbuhkan kesadaran akan pentingnya pengembangan Pariwisata yang nyaman yang akhirnya akan tercapai kesejahteraan Masyarakat kotagede.

2. Saat ini Komunitas Pelestari di kotagede masih sering melakukan gerakan secara parsial yaitu gerakan individu atau gerakan yang kurang memadu dalam gerakan yang menyatu diantara komunitas Pelestari kawasan Pusaka Kotagede, Sehingga, ketika Situs sejarah dan Cagar Budaya di lindungi pembangunan Masyarakat cenderung di tinggalkan, Padahal, membangun Masyarakat dengan pemahaman utuh tidak dapat dilakukan secara terpisah dengan pembangunan fisik suatu wilayah.

3. Dalam Mengembangkan Pariwisata di Kotagede, setidaknya melibatkan tiga komponen penting antara lain pelaku bisnis, pemerintah dan Masyarakat itu 
sendiri,Pelaku bisnis yang ingin menanamkan Modalnya dalam industri Pariwisata, di Kotagede hendaklah jeli dalam menanamkan Modalnya terutama dalam memfasilitasi Wisatawan. Komponen kedua adalah Pemerintahan yang bertanggungjawab mendukung pengembangan dan pelestarian Kotagede dari berbagai segi, Baik pemerintahan desa maupun kota serta pusat, Pemerintah idealnya memberikan Stimulus dan tidak memberikan intervensi yang berlebih terhadap pariwisata di Kotagede, Dukungan Pemerintah dalam memberikan ruang pelatihan dan dana bagi pelestarian dan perkembangan kemandirian masyarakat dapat menciptakan kebijakan yang melindungi warga Kotagede dari perencanaan pembangunan yang tanpa arah. Sedangkan Komponen ketiga adalah Masyarakat, sedari awal harus terbentuk budaya untuk tidak menciptkan kesenjangan Misalnya perbedaan penduduk lokal dan pendatang yang akhirnya akan memunculkan sentimen antar kampung, disinilah tantangan organisasi dan yayasan yang selama ini berkembang untuk pelestarian Kotagede guna memecahkan permasalah ini atau menjembataninya seperti pembentukan pengurus Organisasi haruslah melibatkan semua golongan termasuk pendatang baru serta meberikan edukasi tentang Kotagede. Pembangunan sumber daya manusia haruslah berorientasi pada Kebutuhan Pasar dan kebutuhan dunia Pariwisata yang selaras dengan karakter dan Budaya Masyarakat Kotagede, dilakukan secara terencana dan terorganisir sehingga akan menambah kepercayaan permodalan dalam pembangunan pariwisata di Kotagede serta pemersiapakan sumber Daya Munusia dalam pendampingan wisatawan di Kotagede haruslah dilakukan dengan baik.

\section{Daftar Pustaka}

[1] Ardika, I Wayan. 2007. Pusaka Budaya dan Pariwisata. Bali: Pustaka Larasan.

[2] Salim,Peter MA. 1995. Kamus Besar Indonesia kontemporer. Jakarta: Modern English Press.

[3] Tribunjogja.com. 2012. Kotagede menuju World Heritage City. Diunduh November 2012

[4] Utomo, Budi Cahyo dan Sri rejeki. 1993. Dampak Pengembangan Pariwisata Terhadap Kehidupan Sosial Didaerah Jawa Tengah. Jawa tengah. Deapartement pendidikan dan kebudayaan direktorat JE

[5] Yoeti, Oka. A. 2010. Dasar-dasar pengertian hospitaliti dan pariwisata. Bandung : P.T.ALUMNI

[6] Yoeti,Oka. A. 2012. Pariwisata Budaya Masalah dan Solusinya. Jakarta : Balai Pustaka

[7] Yulianto, Atun. 2017. Analisis Objek Daya Tarik Wisata Favorit Berdasarkan Jumlah Pengunjung Di Daerah Istimewa Yogyakarta. Jurnal Media Wisata Vol.15 No. 2 November 2017. Yogyakarta : STP AMPTA Yogyakarta.

\section{Sumber lain:}

[1] Kelurahan Prenggan. 2012. Potensi Budaya dan Kelompok Pemerhati Budaya, Bantul: Kecamatan Banguntapan

[2] Kelurahan Purbayan. 2012. Potensi wisata dan Obyek budaya Yogyakarta : Kecamatan Kotagede

[3] Peraturan Pemerintah Nomor 25 Tahun 2000 Tentang Perimbangan Keuangan Pusat dan Daerah. Jakarta. Dirjen Perimbangan Keuangan, Kementrian keuangan.

[4] Tap MPR RI No: II/MPR/1988,Bab II A .

[5] UUD RI No. 9 Tahun 1990 Tentang Kepariwisataan, Bandung.Citra umbara

[6] Data penelitian, artikel dan hasil wawancara pada bulan November dan Desember 2012. 